\title{
HOMESCHOOLING SEBAGAI SEKOLAH ALTERNATIF RAMAH ANAK
}

\author{
Rosalina Dewi Heryani \\ Dosen Program Studi Pendidikan Ekonomi Universitas Indraprasta PGRI \\ Email : rosalina.dewi7@gmail.com
}

\begin{abstract}
Abstrak
Homeschooling merupakan sebuah sistem pendidikan atau pembelajaran yang diselenggarakan dirumah dengan memanfaatkan seluruh dunia sebagai ruang kelas. Homeschooling sebagai sekolah alternatif ramah anak dengan pendekatan student center. Tujuan penulisan artikel ini adalah untuk mengetahui lebih mendalam tentang homeschooling. Metode yang digunakan adalah studi kepustakaan dengan mengkaji referensi dari buku dan jurnal. Hasil penulisan ini dapat disimpulkan bahwa kehadiran homeschooling dapat menumbuhkan dan mengembangkan kesadaran belajar bagi anak sesuai dengan fitrahnya, sehingga mereka merasa nyaman dalam belajar, dapat memilih materi pembelajaran sesuai dengan minat, bakat, dan kemampuannya, serta waktu yang fleksibel dibawah bimbingan orang tuanya.
\end{abstract}

Kata Kunci : Homeschooling, Sekolah, Alternatif, Ramah, Anak

\section{PENDAHULUAN}

Kemampuan belajar sepanjang hayat merupakan tujuan utama dari pendidikan. Belajar sepanjang hayat dapat dicapai apabila peserta didik terlatih belajar mandiri dalam hal pengetahuan, penguasaan keterampilan, pengambilan keputusan, dan berinteraksi dengan lingkungannya. Pendidikan harus dapat menjangkau semua lapisan masyarakat, terutama anak-anak. Pendidikan juga harus dapat diselenggarakan secara nyaman dan menyenangkan, tidak membuat peserta didik stress dan akhirnya membuat mereka tidak suka belajar. Disisi lain, pendidikan sejatinya merupakan “aset” bangsa yang paling berharga. Tapi ironisnya, pendidikan yang semula diharapkan menjadi bekal untuk membangun masyarakat Indonesia baru yang tercerahkan, justru sebaliknya menjadi cobaan yang membuat bangsa ini kian terpuruk lebih dalam dan mengerikan. Menurut pendapat Shindunata (Basis, 2008), praktik-praktik pendidikan di sekolah dewasa ini berjalan seperti mesin turbo. Peserta didik dipacu untuk menyerap ilmu sebanyak-banyaknya dalam waktu sesingkat-singkatnya. Pendidikan berjalan sangat mekanis dan menganut prinsip profit oriented (bisnis). Sekolah diorganisasikan seperti target utamanya adalah efisiensi. Akibatnya anak-anak hanya dididik untuk menjadi instrumen untuk meraih efisiensi itu.

Model pendidikan seperti ini berimbas pada pola pembelajaran yang diterapkan di sekolah. Peserta didik hanya diharuskan menghafal tanpa mengetahui makna dari materi-materi yang dihafal. Tidak ada proses dialog antara peserta didik dengan guru. 
Pada gilirannya, proses pembelajaran semacam ini menjadi wahana pembelengguan kreativitas peserta didik. Peserta didik dibebani dengan tugas-tugas yang sebetulnya mereka sendiri tidak memahami makna dari tugas tersebut. Selain itu, sekolah lebih menitikberatkan pada hasil bukan proses. Sehingga seringkali bukan hanya peserta didik, tetapi guru bahkan pengelola sekolah menghalalkan segala cara untuk mencapai hasil yang diinginkan.

Selain itu, banyak peserta didik yang mendapatkan pengalaman kurang menyenangkan selama bersekolah. Salah satu contohnya kasus bullying, bentakan dan kekerasan dari guru. Pengalaman-pengalaman yang kurang berkesan tersebut menimbulkan phobia (ketakutan) terhadap sekolah bagi anak dan orang tua. Melihat kondisi ini, maka perlu dicarikan solusi alternatif bagi anak-anak yang kurang cocok dengan sistem pendidikan formal. Kegiatan homeschooling dianggap menjadi salah satu alternatif yang dapat dipilih. Legalitas Undang-Undang Nomor 20 Tahun 2003 tentang Sistem Pendidikan Nasional. Pada Pasal 27 menyebutkan bahwa “(1) kegiatan pendidikan informal yang dilakukan oleh keluarga dan lingkungan berbentuk kegiatan belajar secara mandiri, dan (2) hasil pendidikan informal diakui sama dengan pendidikan formal dan non formal setelah peserta didik lulus ujian sesuai dengan standar nasional pendidikan”. Berdasarkan Pasal tersebut jelas bahwa homeschooling sebagai salah satu alternatif pembelajaran yang dapat dilakukan oleh masyarakat. Homeschooling berada dibawah naungan Direktorat Pendidikan Kesetaraan, Direktorat Jenderal Pendidikan Luar Sekolah, Kementerian Pendidikan Nasional.

\section{Apa itu Homeschooling?}

Homeschooling lahir di Eropa sekitar tahun 1980-an, ketika sebagian orang tua di Inggris kecewa dengan sistem sekolah yang ada. Menurut mereka sistem pendidikan yang ada tidak mengakomodasikan keunikan masing-masing anak. Dari sana, lahir ide membuat sekolah di rumah yang diajarkan oleh orang tua sendiri. Di Eropa, homeschooling justru dipelopori oleh kaum intelektual yang sudah berpengalaman di sekolah, memiliki waktu luang yang cukup banyak, dan mampu secara keuangan, tetapi mereka kurang percaya dengan sistem pendidikan yang ada. Kalau merunut ke belakang lagi, model homeschooling telah dipakai pada eranya Leonardo da Vinci, Thomas Alfa Edison, Socrates, Ibnu Kindi dan lainnya (Hanaco, 2012:127). 
Dewasa ini di Indonesia istilah homeschooling mulai akrab ditelinga kita. Homeschooling dapat dilakukan oleh semua orang tanpa terkecuali, namun hanya akan berhasil bagi orang-orang yang memiliki disiplin dan memegang komitmen yang kuat. Itu syarat utamanya. Orang tua bebas memilih cara agar anak-anaknya mendapat pendidikan dengan memilih kurikulum yang sudah ditetapkan Departemen Pendidikan setempat. Cara belajarnya pun terserah pada kesepakatan keluarga. Kegiatan homeschooling perlu dilaporkan ke Dinas Pendidikan setempat agar peserta homeschooling mendapat ijazah resmi dari pemerintah. Setiap orang yang lulus ujian kesetaraan Paket A, Paket B atau Paket C masing-masing memiliki hak eligibilitas yang sama dan setara dengan pemegang ijazah SD/MI, SMP/MTs, dan SMA/MA/SMK untuk dapat mendaftar pada satuan pendidikan yang lebih tinggi.Jika dibandingkan antara homeschooling dengan program kejar paket hanya berbeda dari segi nama/istilah dan fasilitas belajarnya saja. Namun persamaannya adalah sama-sama menempuh ujian akhir Paket A untuk SD, Paket B untuk SMP atau Paket C untuk SMA.

Dalam Kamus Besar Bahasa Indonesia, terjemahan homeschooling adalah “sekolah rumah”. Istilah ini dipakai secara resmi oleh Departemen Pendidikan Nasional. Selain sekolah rumah homeschooling terkadang diterjemahkan dengan istilah "sekolah mandiri”. Homeschooling merupakan model pendidikan alternatif selain di sekolah.

Ada beberapa pendapat tentang pengertian homeschooling. Menurut Edy (2013:157) Homeschooling artinya melakukan aktivitas pembelajaran di rumah, tetapi homeschooling bukan berarti memindahkan kurikulum sekolah ke rumah. Homeschooling juga merupakan pendidikan alternatif yang terjangkau oleh semua kalangan, memberikan kemerdekaan untuk memilih model dan waktu pembelajaran yang cocok bagi anak. Kurikulumnya bisa dibuat sesuai dengan kebutuhan dan tujuan akhir pembelajaran bagi anak.

Menurut Carol (Griffith, 2008) didalam buku "Sekolah di Rumah: Memanfaatkan seluruh dunia sebagai ruang kelas”, pendidikan tanpa sekolah berarti mempelajari apa yang kita inginkan, saat kita menginginkannya, dengan cara yang kita inginkan, di tempat yang kita inginkan, untuk alasan kita sendiri. Pembelajaran diarahkan pada si pembelajar, penasihat atau fasilitator dicari sesuai keinginan si pembelajar. Tidak ada kurikulum, rencana pelajaran, jadwal, atau agenda. Kebanyakan 
pembelajaran dilakukan dengan hening, bahkan tidak tampak, karena tidak ada fokus untuk menciptakan banyak "produk".

Menurut Hanaco (2012:5) Dalam keseharian homeschooling biasa diartikan sebagai “sekolah rumah". Hal penting yang mendasari homeschooling adalah pendidikan dilaksanakan sendiri oleh keluarga, difokuskan pada kepentingan dan kebutuhan anak, dengan tujuan untuk mengembangkan semua potensi anak semaksimal mungkin.

Secara sederhana homeschooling bisa dijelaskan sebagai model pendidikan berbasis rumah, dengan orang tua sebagai penanggung jawab aktif serta fokus pada kepentingan dan kebutuhan anak-anaknya. Jadi homeschooling bukanlah sebuah lembaga. Orang tua sendiri yang menyelenggarakan homeschooling. Dalam perkembangannya orang tua dapat bekerja sama dengan lembaga lainnya untuk memperlancar proses homeschooling, salah satunya adalah dengan bergabung dengan komunitas homeschooling.

\section{Jenis-Jenis Kegiatan Homeschooling}

Ada tiga jenis homeschooling yang dikenal di Indonesia berdasarkan penerapannya, seperti yang diungkapkan oleh Mulyadi (2007:36) antara lain :

1. Homeschooling Tunggal adalah homeschooling yang dilaksanakan oleh orang tua dalam satu keluarga tanpa bergabung dengan lainnya. Biasanya homeschooling jenis ini diterapkan karena adanya tujuan atau alasan khusus yang tidak dapat diketahui atau dikompromikan dengan komunitas homeschooling lain. Alasan lain adalah karena lokasi atau tempat tinggal si pelaku homeschooling yang tidak memungkinkan berhubungan dengan komunitas homeschooling lain.

2. Homeschooling Majemuk adalah homeschooling yang dilaksanakan oleh dua atau lebih keluarga untuk kegiatan tertentu sementara kegiatan pokok tetap dilaksanakan oleh orang tua masing-masing. Alasannya terdapat kebutuhan-kebutuhan yang dapat dikompromikan oleh beberapa keluarga untuk melakukan kegiatan bersama.

3. Komunitas Homeschooling adalah gabungan beberapa homeschooling majemuk yang menyusun dan menentukan silabus, bahan ajar, kegiatan pokok (olahraga, musik/seni, dan bahasa), sarana/prasarana, dan jadwal pembelajaran. Komitmen penyelenggaraan antara orang tua dan komunitasnya kurang lebih 50:50.

Dalam buku Ayah Edy Menjawab, Edy (2013:152) menyebutkan bahwa jenis

sistem homeschooling terbagi menjadi tiga antara lain :

1. Personal Homeschooling yaitu orang tuanya sendiri yang mengajarkan langsung kepada anak, tanpa meminta bantuan siapa pun.

2. Homeschooling Tutorial yaitu dengan memanggil guru les atau mengikutkan anak kursus dibidang yang disukai anak, tujuannya agar anak menjadi spesialis. 
3. Komunitas yaitu jika orang tua tidak mampu mengajari, bisa diikutkan dalam komunitas homeschooling.

\section{Konsep Dasar Homeschooling}

Menurut Edy (2013:155), konsep dasar homeschooling antara lain :

1. Homeschooling akan lebih fokus pada 4 hal pokok yaitu Activities Plan dengan memberikan stimulasi kepada anak sehingga anak mengetahui berbagai macam hal. Mencari media pembelajaran melalui aktivitas harian. Melakukan observasi hasil pencapaian masing-masing anak secara individual tanpa membandingkan dengan pencapaian anak lain. Mengambil jalur evaluasi formal melalui Sistem Pusat Kegiatan Belajar Masyarakat (PKBM) dan Ujian Paket.

2. Prinsip-prinsip pokok yang dikembangkan yaitu mengembangkan kreativitas, akhlak dan memberikan kesempatan kepada anak untuk bertanya tentang apa saja.

3. Definisi cerdas dan berkarakter secara sederhana adalah apabila seorang anak selalu tertarik untuk mengetahui, mencoba, menggali, dan aktif menggunakan perasaan dan logikanya, serta selalu berusaha mencari cara memecahkan masalahnya dan masalah orang lain. Dengan fokus mengembangkan kecerdasan dan karakter anak.

4. Mengembangkan kemampuan anak bukan sesuai kemauan dan ambisi orang tuanya tapi kepada potensi unggul alamiah bawaan lahirnya.

5. Mengarahkan profesi anak dengan mengedepankan passion yang dimiliki sang anak sehingga ia melakukannya dengan sepenuh hati, bahagia dan bermanfaat bagi diri dan orang lain.

6. Sistem evaluasi tidak ditekankan pada test dan nilai melainkan pada perilaku kecerdasan dan akhlaknya yang dapat dirasakan atau dilihat langsung.

7. Menjadikan anak sebagai alat ukur keberhasilan kurikulum dan program pembelajaran dan bukan sebaliknya.

\section{Model Pembelajaran Homeschooling}

Menurut Sumardiono (2007:21) pendekatan yang digunakan homeschooling dalam proses pembelajaran memiliki rentang yang lebar antara yang sangat tidak terstruktur hingga yang sangat terstruktur, seperti belajar di sekolah. Beberapa model pembelajaran yang diterapkan dalam homeschooling antara lain :

1. School at home adalah model pendidikan yang serupa dengan yang diselenggarakan di sekolah. Hanya saja, tempatnya tidak di sekolah tetapi dirumah.

2. Unit Studies adalah model pendidikan yang berbasis pada tema. Dalam pendekatan ini, peserta didik tidak belajar satu mata pelajaran tertentu , tetapi mempelajari banyak mata pelajaran sekaligus melalui sebuah tema. Metode ini berkembang atas pemikiran bahwa proses belajar seharusnya terintegrasi, bukan terpecah belah.

3. Charlote Manson atau The Living Books adalah model pendidikan melalui pengalaman dunia nyata. Pendekatannya dengan mengajarkan kebiasaan baik, keterampilan dasar (membaca, menulis, matematika) serta mengekspos anak dengan pengalaman nyata. 
4. The Classical adalah model pendidikan yang dikembangkan sejak abad pertengahan. Pendekatan ini menggunakan kurikulum yang terstruktur berdasarkan tiga tahap perkembangan anak yang disebut Trivium. Penekanan metode ini adalah kemampuan ekspresi verbal dan tertulis, pendekatannya berbasis teks/literatur.

5. The Walddorf adalah model pendidikan yang dikembangkan oleh Rudolf Steiner, banyak ditetapkan di sekolah-sekolah alternatif Walddorf di Amerika. Karena Steiner berusaha menciptakan setting sekolah yang mirip keadaan rumah, metodenya mudah diadaptasi untuk homeschooling.

6. The Montessori adalah model pendidikan yang dikembangkan Dr. Maria Montessori. Pendekatan ini mendorong penyiapan lingkungan pendukung yang nyata dan alami, mengamati proses interaksi anak-anak di lingkungan, serta terus menumbuhkan lingkungan sehingga anak-anak dapat mengembangkan potensinya, baik secara fisik, mental maupun spiritual.

7. Unschooling adalah pendekatan yang berangkat dari keyakinan bahwa anak-anak memiliki keinginan natural untuk belajar. Jika keinginan itu difasilitasi dan dikenalkan dengan pengalaman di dunia nyata, meraka akan belajar lebih banyak daripada melalui metode lainnya. Unschooling tidak berangkat dari textbook, tetapi dari minat anak yang difasilitasi.

8. The Ecletic adalah pendekatan yang memberikan kesempatan pada keluarga untuk mendesain sendiri program homeschooling yang sesuai, dengan memilih atau menggabungkan dari sistem yang ada.

Melalui pendekatan-pendekatan diatas proses belajar mengajar akan dapat menciptakan suasana yang lebih menyenangkan serta akan menciptakan peserta didik yang lebih kreatif dan mandiri, mereka lebih bebas dalam mengekspresikan karya-karya mereka dan membuat mereka tidak tergantung pada orang lain, karena pada dasarnya peserta didik memiliki kecenderungan dan kebutuhan dasar untuk mengembangkan potensi semaksimal mungkin, seorang guru atau orang tua sifatnya hanya mendampingi, membimbing serta memfasilitasi anak untuk belajar, proses belajar sepenuhnya disesuaikan dengan kebutuhan anak.

\section{Manfaat Homeschooling}

Secara umum homeschooling dapat tetap berjalan seiring dengan sekolah formal. Anak-anak tetap dapat menjalankan kegiatan belajar di sekolah formal, namun apa yang kurang di sekolah formal ditambal dengan homeschooling. Atau dengan kata lain, homeschooling dapat dijalankan untuk mendukung kegiatan sekolah formal.

Menurut Mulyadi (2007:42) Dalam bukunya Homeschooling Keluarga Kak Seto, beliau memaparkan ada beberapa manfaat homeschooling antara lain : 
1. Anak-Anak Menjadi Subjek Belajar.

Melalui homeschooling, anak diberi peluang untuk menentukan materi pelajaran sesuai keinginannya dan juga gaya belajarnya. Dengan menjadikan anak sebagai subjek belajar, maka belajar yang diselenggarakan si anak dapat berlangsung secara nyaman dan menyenangkan.

2. Objek yang Dipelajari Sangat Luas dan Nyata.

Homeschooling akan membawa anak-anak untuk belajar di dunia nyata, di alam yang sangat terbuka. Disamping itu, objek yang dipelajari anak pun bisa sangat luas, seluas langit dan bumi.

3. Ajang Menanamkan Cinta Belajar.

Homeschooling dapat menyadarkan para orang tua bahwa belajar bisa dilakukan di mana saja, termasuk di rumah. Secara naluriah anak sejak berada di kandungan ibunya sudah dilengkapi dengan kemauan kuat untuk belajar. Namun perlu didukung oleh lingkungan belajar yang kondusif agar semangat dan cinta belajar anak dapat tumbuh dan berkembang maksimal.

4. Memberikan Kemudahan Belajar Karena Fleksibel.

Kunci utama penyelenggaraan homeschooling adalah adanya kelenturan atau fleksibilitas. Jadi tidak boleh kaku dan terlalu terstruktur sebagaimana sekolah formal, apabila tidak flesibel maka homeschooling justru akan kehilangan makna utamanya.

5. Mendukung Belajar Secara Konstektual.

Metode Homeschooling sangat kontekstual karena seorang anak dapat mengaitkan isi materi yang dipelajarinya dengan pengalaman mereka sendiri, dan menemukan makna serta memberi alasan kepada mereka untuk belajar.

\section{Kekuatan dan Kelemahan Homeschooling}

Sebagai sebuah pendidikan alternatif homeschooling juga mempunyai beberapa

kekuatan dan kelemahan (Adilistiono, 2010).

Kekuatan homeschooling antara lain :

1. Lebih mengedepankan kemandirian dan kreativitas individual bukan pembelajaran secara klasikal.

2. Memberikan peluang untuk mencapai kompetensi individual semaksimal mungkin sehingga tidak selalu harus terbatasi untuk membandingkan dengan kemampuan tertinggi, rata-rata, atau bahkan terendah.

3. Terlindungi dari tawuran, kenakalan, pergaulan menyimpang, dan konsumerisme.

Kelemahan homeschooling antara lain :

1. Anak-anak yang belajar di homeschooling kurang berinteraksi dengan teman sebaya dari berbagai status sosial yang dapat memberikan pengalaman berharga untuk belajar hidup di masyarakat.

2. Sekolah merupakan tempat belajar yang khas yang dapat melatih anak untuk bersaing dan mencapai keberhasilan yang setinggi-tingginya.

3. Homeschooling dapat mengisolasi peserta didik dari kenyataan-kenyataan yang kurang menyenangkan, sehingga dapat berpengaruh pada perkembangan individu. 
4. Apabila anak hanya belajar di homeschooling kemungkinan ia akan terisolasi dari lingkungan sosial yang kurang menyenangkan, sehingga ia kurang siap untuk menghadapi berbagai kesalahan atau ketidakpastian.

Untuk itu demi kesuksesan program pendidikan ini, disarankan adanya kerjasama guru, orang tua dan peserta didik, dapat dibangunnya serta ditumbuh kembangkannya semua potensi yang dimiliki oleh anak secara optimal, alami, dan diberikannya kebebasan kepada peserta didik untuk memilih bahan pelajaran dan mempelajarinya sesuai minat dan kemampuannya.

\section{SIMPULAN}

Homeschooling merupakan salah satu sekolah alternatif ramah anak dimasa depan, karena homeschooling dapat mempercepat tercapainya masyarakat belajar yang merupakan salah satu ciri masyarakat madani. Potret pendidikan Indonesia selama ini masih saja mengejar tingkat kuantitas dengan menerapkan standar kelulusan nasional hanya dengan melihat beberapa nilai mata pelajaran tanpa melihat keunggulan dan prestasi peserta didik lainnya yang bersifat non akademik, dimana pendidikan hanya cenderung mengejar dan menghabiskan materi kurikulum mata pelajaran tanpa memperhatikan kemampuan daya serap kecerdasan anak. Model pendekatan yang seperti ini sungguh bertentangan dengan konsep pendidikan yang mengedepankan unsur humanistik.

\section{DAFTAR PUSTAKA}

\section{Buku :}

Edy, Ayah. 2013. Ayah Edy Punya Cerita. Jakarta:Naura Books, p:157.

Edy, Ayah. 2013. Ayah Edy Menjawab. Jakarta:Naura Books, p:152.

Griffith, Mary. 2008. Sekolah Di Rumah:Memanfaatkan Seluruh Dunia Sebagai Ruang Kelas. Bandung:Penerbit Nuansa, p:17.

Hanaco, Indah. 2012. I Love Homeschooling:Segala Sesuatu Yang Harus Diketahui Tentang Homeschooling. Jakarta:Gramedia Pustaka Utama, p:5, 127.

Mulyadi, Seto. 2007. Homeschooling Keluarga Kak Seto:Mudah, Murah, Meriah, dan Direstui Pemerintah. Bandung:Kaifa, pp:36-42. 
Sumardiono. 2007. Homeschooling-A Leap For Better Learning-Lompatan Cara Belajar. Jakarta:PT. Elex Media Komputindo Kelompok Gramedia, p:21.

Jurnal :

Adilistiono. 2010. Homeschooling Sebagai Alternatif Pendidikan. Jurnal Pengembangan Humaniora,Volume 10 Nomor 1.

\section{Perundang-Undangan :}

Undang-Undang RI No.20 Tahun 2003 Tentang Sistem Pendidikan Nasional, p:10.

\section{Majalah :}

Shindunata. 2008. Melawan Pendidikan Turbo Refleksi Ki Hajar Dewantara. Majalah Basis Nomor 07/08, p:15. 